\title{
Motivational factors in sales team management and their influence on individual performance
}

\author{
Os factores motivacionais na gestão da equipa de vendas e a sua Influência no desempenho individual
}

\section{Teresa Santos Ferreira}

Institute of Business Management, Rua Eng. Ferreira Dias, 728, 4100-246 Porto, Portugal, coordenacaocientifica@instituteofbusinessmanagement.pt

\section{Abstract}

This study analysed the intrinsic and extrinsic motivational factors of sales teams and these factors' influence on team members' performance in a pharmaceutical industry context. A quantitative survey was conducted by distributing a questionnaire to a sample of 326 salespeople working in Portugal. The data were analysed using two statistical approaches: descriptive analysis of the variables and structural equation analysis. The results show that the intrinsic factors that best explain sales teams' motivation are 'personal goals' and 'skills acquired'. Extrinsic factors that best explain motivation in this context are 'transparency and loyalty in interactions with bosses' and 'trust in the company'. 'Participation in the growth of the company's business' and 'attitude' are the factors that most influence team performance in terms of results and behaviour, respectively.

Keywords: Intrinsic factors, extrinsic factors, motivation, performance, sales team.

\section{Resumo}

Este estudo analisou os factores motivacionais intrínsecos e extrínsecos da equipa de vendas e a sua influência no desempenho dos membros da equipa no contexto da indústria farmacêutica. Foi efectuada uma pesquisa quantitativa, distribuindo um questionário a uma amostra de 326 comerciais que actuam em Portugal. Os dados foram analisados com recurso a duas abordagens estatísticas: a análise descritiva das variáveis, e análise de equações estruturais. Os resultados revelam que os factores intrínsecos que melhor explicam a motivação da equipa de vendas são as "metas pessoais" e "competências adquiridas". Os factores extrínsecos que melhor explicam a motivação neste contexto são a "transparência e lealdade no contacto com as chefias" e "confiança na empresa". A "participação no crescimento dos negócios da empresa" e a "Atitude" são os factores com maior peso no desempenho ao nível dos resultados e comportamental, respectivamente.

Palavras-chave: Factores intrínsecos; factores extrínsecos; motivação; desempenho; equipa de vendas.

\section{Introduction}

Motivation is an issue of particular interest to organisations since it boosts performance, and motivated employees in direct contact with customers make an essential contribution to organisations' success. In this context, the success of organisations depends increasingly on the management and leadership of people, including keeping these individuals motivated.

Leading companies and keeping them competitive in the current economic context of pervasive instability and constant change is a major challenge. Commercial departments play a decisive role because they are responsible for managing and developing the entire relationship between companies and their customers and partners. Since people are the most precious asset of any organisation and organisations' connections with clients are usually directly dependent on the commercial department, individual employees' performance within this department is clearly a critical factor in the success of organisations in a global macroeconomic context that is increasingly competitive and volatile.

Customers are increasingly better informed and more demanding, and they have a wide range of options that can meet their needs and requirements. Thus, product and/or service quality contributes to greater competitiveness between companies. Rodrigues, Guerra and Câmara (1997) point out that managers have to recognise that success comes not only from advanced technology, solid financial bases and relevant positions in the market but also, fundamentally from motivated employees with appropriate professional profiles that contribute to their performance of work functions and high productivity.

Organisations rely on the effective use of teamwork to achieve competitive advantage. Maximising team results means not only optimising employees' performance, which corresponds to achieving the individual objectives of each team member, but also encouraging the intra-team balance that comes from cooperation between members.

A competent sales force is one of the most important elements in successful companies (Churchill, Ford, Walker, Johnston \& Tanner, 2000) as this is the bridge between firms and their customers. The specifics of sales people's jobs make their work different to other employees' jobs since sales people both represent their company to clients and represent clients to the company (Stanton \& Spiro, 2000).

The sales force is the link that personalises each company for customers, functioning as a differentiating factor that creates more competitive advantages for companies. Sale people are the most 'visible' representatives of companies, and sales teams are usually the first and often the only employees who are in direct contact with customers. Therefore, companies' sales force play a key role in diagnosing customer needs, developing customer trust, and strengthening commercial relations. In addition, sales teams are responsible for implementing their company's marketing strategies, as these teams not only represent the organisations to their customers but also keep companies informed about clients' unmet needs (Spiro, Rich \& Stanton, 2009). In this sense, it is fundamental that managers be able to oversee and keep their sales force motivated by, identified with and committed to the success of their organisation.

With the evolution from a hard sell paradigm to a soft sell paradigm, concepts about sales performance have become more complex. Thus, a distinction can be made between performance through results and performance in behaviour. The first is evaluated by the results that companies' sales force achieves through their efforts and competences (Anderson \& Oliver, 1987) or the results 
that can be directly attributed to these professionals (Walker, Churchill \& Ford, 1977), such as more clients, contributions to the growth of their company's businesses (i.e. market share) and fulfilment of goals and objectives. Behavioural performance consists of sales force activities and strategies in their work (i.e. teamwork, attitudes, commitment and sales plans, sales adaptability, sales support and sales presentation). These activities can be linked directly to sales (i.e. adaptive selling) or comprise activities not directly linked to sales, such as sales support (Piercy, Cravens, Lane \& Vorhies, 2006).

With regard to the factors that influence motivation the most, experts' opinions are not unanimous since these vary according to stakeholders, scholars, managers and employees. The present research's contribution is that we sought to explore the issues related to the motivation factors of sales teams in Portugal's pharmaceutical sector.

Currently, the challenges that companies' sales force face are notably greater than those of other employees within companies, given the direct influence these teams have on companies' revenues and survival, as well as the levels of demand and need for follow-up and fulfilment of sales objectives. The same applies to managers who directly or indirectly coordinate sales teams. Therefore, sales managers who want to succeed must be sensitive to the challenges of sales positions and all activities inherent in sales.

Given these assumptions, the purpose of this study was to examine the intrinsic and extrinsic motivational factors that influence companies' sales force in their job performance at the level of behaviour and results within organisations. We sought to determine, on the one hand, which intrinsic and extrinsic factors most influence and contribute to the motivation of sales teams and, on the other hand, how motivation influences behavioural performance and performance results. This study's findings on these variables have important practical implications at the organisational level.

The present research focused on businesses in Portugal's pharmaceutical sector because their sales force is considered a differentiating factor in companies' competitive advantage. This investigation addressed two main questions:

1) What are the intrinsic and extrinsic factors that best explain the level of motivation of sales teams?

2) Does motivation influence behavioural performance and performance results?

\section{Literature Review}

\subsection{Motivation}

Motivation is an abstract construct that has been widely used in the human sciences and that is amenable to many approaches. Motivation at work has been presented over the years as a central variable in organisational life. Interest in this topic arose in the first quarter of the twentieth century, when researchers began to recognise the problematic aspects of the Taylorist model of the scientific organisation of work and the importance of the "human factor' in organisations.
Since then, many studies have been conducted and theories developed that have sought to explain the internal functioning of the impulse that leads individuals to work to achieve certain objectives and that - with different degrees of empirical support is associated with company productivity and employee performance and personal fulfilment. On the one hand, managers find it difficult to identify what motivates each employee of their organisation, while, on the other hand, companies face increasing difficulties in this area because motivation is not something that can simply be given to employees.

Based on a combination of various definitions, the concept of motivation can be understood as the internal force or impulse that predisposes individuals to an action to achieve an objective. Being motivated means being moved to do something.

The motivation of their sales force is a controversial topic among sales managers. These managers - once identified as individuals who 'move' their employees - can seek to direct their sales teams' behaviour in the pursuit of their organisation's objectives. However, these efforts run up against the complexity of human nature. Each individual is a single universe, conditioned by a multitude of variables. While managers find it challenging to identify what motivates each employee of their organisation, they also have to deal with increased difficulties in achieving their objectives since motivation is not something that can be given to sales people.

Motivation is central to understanding human behaviour. Without motivation, individuals can rarely achieve good results in their performance. The secret of success can be said to be largely related to motivation. It activates and directs behaviour. Currently, the main objective of management is to identify the ideal 'formula' to guarantee a high and sustainable level of motivation, as they seek to harmonise and optimise the interaction between the organisational and personal objectives of their employees. In this context, a review of the main theories of motivation is particularly relevant, in order to understand better the motivation of companies' sales force. People who produce good results clearly tend to feel satisfied and self-fulfilled.

\subsubsection{Theories of Motivation}

Throughout the last century, theories of motivation evolved to deal with different levels of organisational development, with several theses developed along with their respective theories or models of support. According to Rosa (1994), two types of motivational theories can be identified. The first are classical theories that are identified as prescriptive models seeking to inform managers about how to motivate their employees. This category includes the works of Taylor (1911) and McGregor (1960). The second group is contemporary theory, which seeks an explanation for the phenomena inherent in the motivational cycle. At their most basic level, these are interpretative models of motivational systems. The work of Alderfer (1972), Herzberg (1968) and Maslow (1954), as well as process theories (McClelland, 1961 and Vroom, 1964), are considered part of this category.

Within contemporary theories of motivation, two major groups can be distinguished: content theories and process theories. The first explain motivation through an analysis of motivational 
factors, while the second analyse how motivation is expressed in performance (Cunha, Rego, Cunha \& Cardoso-Cabral, 2007). Content theories include Maslow's hierarchy of needs theory, motive theory, bifactorial theory and job characteristics theory.

Table 1 summarises the theories of motivation.

\section{Table 1 - Summary of motivation theories}

\begin{tabular}{|c|c|}
\hline $\begin{array}{l}\text { Hierarchy of needs theory } \\
\text { Maslow (1954) }\end{array}$ & $\begin{array}{l}\text { This model is based on a hierarchy of five needs. Unmet needs are the main motivators of human } \\
\text { behaviour, with priority given first to the most basic needs and then on up to the highest needs. If the } \\
\text { needs of a given level are satisfied, the level immediately following that becomes important, leaving the } \\
\text { previous level to be a motivating factor. The source of motivation is basic satisfaction and more } \\
\text { intellectual desires. Employees have, therefore, hierarchically defined needs: physiological, safety, social, } \\
\text { esteem and self-fulfilment. These evolve in this order in terms of importance and influence. }\end{array}$ \\
\hline $\begin{array}{l}\text { Motivation-hygiene theory } \\
\text { Herzberg (1968) }\end{array}$ & $\begin{array}{l}\text { The motivation-hygiene theory suggests that individuals have two groups of independent needs: } \\
\text { motivating factors and hygienic factors. Motivating factors are responsible for satisfaction, and hygienic } \\
\text { factors lead to pain avoidance and the relief of short-term discomfort. The sources of motivation are the } \\
\text { external environment and work. Employees seek enrichment through jobs as new sources of motivation } \\
\text { rather than as a way to avoid dissatisfying work. }\end{array}$ \\
\hline $\begin{array}{l}\text { Theories } X \text { and } Y \\
\text { McGregor (1960) }\end{array}$ & $\begin{array}{l}\text { This theory presents two antagonistic approaches, theories } X \text { and } Y \text {, regarding human behaviour in } \\
\text { organisations. Theory } X \text { (i.e. conventional conceptions of management) sees the average man as indolent } \\
\text { by nature, working as little as possible, lacking ambition, disliking responsibility and resisting change. In } \\
\text { contrast, theory } Y \text { (i.e. the new management approach) views human beings as capable of self-orientation } \\
\text { and self-control and able to generate ideas that improve organisational effectiveness. The } Y \text {-theory } \\
\text { approach has motivational characteristics. }\end{array}$ \\
\hline $\begin{array}{l}\text { Vroom's expectancy theory } \\
\text { Vroom (1964) }\end{array}$ & $\begin{array}{l}\text { This approach considers behaviour and performance to be the result of conscious choices, and, therefore, } \\
\text { individuals' motivation to expend effort is based on their expectation of success. The source of motivation } \\
\text { is based on high levels of valence, instrumentality and expectations. Employees will tend to perform tasks } \\
\text { when greater value is attributed to the reward and the probability of performing the task well. }\end{array}$ \\
\hline $\begin{array}{l}\text { ERG theory } \\
\text { Alderfer (1972) }\end{array}$ & $\begin{array}{l}\text { This theory argues that motivation arises from the drive to satisfy three types of needs: existence, } \\
\text { relationship and growth. In this theory, individuals can be motivated by needs at different levels. The } \\
\text { frustration of needs at a higher level leads people to return to needs at a lower level, even if these have } \\
\text { already been fulfilled. The source of motivation is the satisfaction of needs. Employees have existence, } \\
\text { relationship and growth needs and move flexibility between levels of the hierarchy of needs, since they } \\
\text { feel simultaneously motivated by several levels to achieve the basic goal of self-realisation. }\end{array}$ \\
\hline $\begin{array}{l}\text { Job characteristics model } \\
\text { Hackman and Oldham (1976) }\end{array}$ & $\begin{array}{l}\text { This model postulates that five characteristics of work contribute to employees' income and motivation. } \\
\text { They will tend to increase their work performance levels according to job characteristics associated with } \\
\text { variety, identity, meaning, autonomy and feedback within their organisation. }\end{array}$ \\
\hline $\begin{array}{l}\text { Learned needs theory } \\
\text { McClelland (1961) }\end{array}$ & $\begin{array}{l}\text { This theory states that motivation results from the drive to satisfy three types of needs: achievement, } \\
\text { affiliation and power. These needs have differing weights among individuals, varying over time and } \\
\text { depending heavily on their interaction with their environment. The source of motivation is socially } \\
\text { acquired needs. Employees have achievement, affiliation and power needs, but one of these has more } \\
\text { influence than the rest. }\end{array}$ \\
\hline $\begin{array}{l}\text { Goal-setting theory } \\
\text { Locke and Latham (1984) }\end{array}$ & $\begin{array}{l}\text { This theory explains that, for individuals to be motivated and perform well, they need to set goals and } \\
\text { outline objectives that guide their actions. Their source of motivation is the objectives they want to } \\
\text { achieve. Employees will tend to meet their goals (i.e. sources of emotions and desires). }\end{array}$ \\
\hline $\begin{array}{l}\text { Self-determination theory } \\
\text { Deci and Ryan (1985) }\end{array}$ & $\begin{array}{l}\text { This theory distinguishes between various types of motivation based on the various reasons or goals that } \\
\text { give rise to actions. This approach explains that motivation must be seen as a continuous process that } \\
\text { goes from the absence of motivation to intrinsic motivation and, finally, extrinsic motivation. The source } \\
\text { of motivation is the satisfaction of internal needs. Employees will tend to look for challenges that are } \\
\text { compatible with their skills acquisition capabilities, based on their interaction with stimuli that provoke } \\
\text { them to actions meant to achieve the goal of self-determination. }\end{array}$ \\
\hline
\end{tabular}

Source: Author.

\subsection{Performance}

Most organisations currently use performance goals to influence their employees' behaviour. However, the results are not always what these organisations expect. As a result, managers are always concerned about whether performance goals have the right impact on individuals' behaviour and organisational performance. These goals have been conceptualised as defining the frontier that differentiates success from failure. Performance targets, especially in the area of sales, are almost always associated with monetary incentives, so-called 'bonuses'. In addition to their base salary, sales people are entitled to receive these monetary incentives if they meet or exceed the objectives stipulated by their organisation. Churchill, Ford, Hartley and Walker (1985, p. 116) argue that 'performance is behaviour evaluated in terms of its contributions to the goals of the organisation'. According to Churchill et al. (1985) and Küster and Canales (2008), performance is defined as the result of behaviour, which is assessed in terms of contribution to companies' objectives, and determined by factors that, in part, managers can control. Table 2 presents a general summary of the components of behavioural performance and performance results of sales teams. 
Table 2 - Components of sales team behavioural performance and performance results

\begin{tabular}{|c|c|}
\hline $\begin{array}{l}\text { Sales Team Behavioural } \\
\text { Performance }\end{array}$ & Sales Team Performance Results \\
\hline Technical knowledge & More customers/new accounts \\
\hline Attitude & $\begin{array}{l}\text { Participation in the growth of the } \\
\text { company's business (i.e. market } \\
\text { share) }\end{array}$ \\
\hline Teamwork & Fulfilment of goals and objectives \\
\hline Commitment/involvement & Client satisfaction \\
\hline $\begin{array}{l}\text { Customer support and } \\
\text { other support activities }\end{array}$ & $\mathrm{N} / \mathrm{a}$ \\
\hline Plans & $\mathrm{N} / \mathrm{a}$ \\
\hline
\end{tabular}

Source: Adapted from Babakus, Craven, Johnston and Moncrief (1996),

Behrman and Perrault (1982), Cravens, Ingram, LaForge and Young (1993).

\section{Methodology}

This study was based on descriptive research that used a questionnaire to collect the data. For greater convenience, the type of sampling adopted was non-probabilistic. The survey focused on the pharmaceutical sector, specifically targeting companies' sales force that operate in Portugal, for a total sample of 326 employees. For this study, we opted for three approaches in the analysis of quantitative data. A more classical approach was used to characterise the sociodemographic and variable data, as well as simple descriptive statistics. The other approach applied was structural equation modelling, with the objective of validating the proposed conceptual model. Table 3 summarises the intrinsic and extrinsic motivational factors extracted from the literature review.

Table 3 - Intrinsic and extrinsic factors

\begin{tabular}{|l|l|l|}
\hline \multicolumn{2}{|c}{ Intrinsic Factors } \\
\hline F1 Autonomy & F5 Skills acquired \\
\hline F2 Responsibility & $\begin{array}{l}\text { F6 Personal and professional } \\
\text { fulfilment }\end{array}$ \\
\hline F3 Competition - being the best & F7 Appreciation for business \\
\hline F4 Project challenge & F8 Personal goals \\
\hline F9 Status & F21 Job stability \\
\hline F10 Possibility of promotion & $\begin{array}{l}\text { F22 Participation in top } \\
\text { management meetings }\end{array}$ \\
\hline F11 Work environment & F23 Leadership style \\
\hline F12 Productivity award & F24 Work conditions \\
\hline $\begin{array}{l}\text { F13 Royalties materials (e.g. cars, } \\
\text { mobile phones and trips) }\end{array}$ & F25 Safety at work \\
\hline F14 Leadership recognition & F26 Company politics \\
\hline F15 Contact with customers & F27 Social relationships \\
\hline F16 Continuous training & F28 Trust in the company \\
\hline $\begin{array}{l}\text { F17 Career development } \\
\text { opportunity }\end{array}$ & F29 Leisure activities \\
\hline $\begin{array}{l}\text { F18 Transparency and loyalty in } \\
\text { interactions with bosses }\end{array}$ & F30 Direct access to hierarchy \\
\hline $\begin{array}{l}\text { F19 Freedom of action in } \\
\text { interactions with customers }\end{array}$ & F31 Participation in objectives \\
\hline $\begin{array}{l}\text { F20 Interpersonal relationship } \\
\text { between colleagues and } \\
\text { managers }\end{array}$ & F32 Communication between \\
managers
\end{tabular}

Source: Adapted from the theories of Almeida (1996), Chiavenato (1999), Deci and Ryan (1985), Hackman and Oldham (1976), Herzberg (1968), Locke and Latham (1984), Maslow (1954), McClelland (1961), McGegor (1960), Shapiro (1988) and Vroom (1964).
Based on the literature review of the most important research in the field and the variables defined for the present study, several hypotheses were elaborated as summarised in the theoretical model presented in Figure 1.

Figure 1 - Conceptual framework of proposed theoretical model

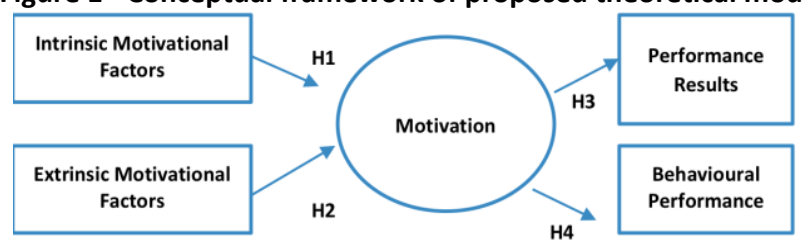

Source: Author.

The hypotheses developed are as follows:

- H1: Intrinsic motivational factors (1, 2, 3, 4, 5, 6, 7 and 8) influence the motivation of sales teams.

- H2: Extrinsic motivational factors $(9,10,11,12,13,14,15,16$, $17,18,19,20,21,22,23,24,25,26,27,28,29,30,31$ and 32 ) influence the motivation of sales teams.

- H3: Motivation influences sales teams' performance results.

- H4: Motivation influences sales teams' behavioural performance.

\section{Results}

The sample is characterised by male $(60 \%)$ and female $(40 \%)$ individuals, with those aged between 30 and 50 years representing the majority of respondents (66\%). Most respondents were married, and they had between one and two children.

Regarding qualifications and competencies, respondents reported having a bachelor degree (57.1\%) and/or doctorate (12.8\%). Most respondents had between 5 and 15 years of work experience. This reflects that the pharmaceutical industry's core business sells highly technological products that require their professionals to be highly qualified.

As shown in Figure 2 and Figure 3, the average scores - based on a seven-point Likert scale - for all intrinsic factors are high and close to each other, with the highest value given to 'personal goals' and the lowest to 'competition'. For extrinsic factors, the average scores are also high and close to each other, with the highest value going to 'transparency and loyalty in interactions with bosses' and the lowest value to 'status'.

Figure 2 - Measures of centrality of intrinsic motivational factors (average)

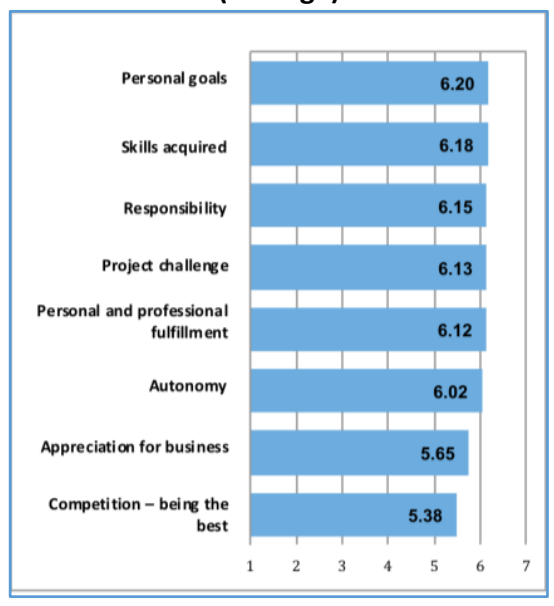

Source: Author. 
Figure 3 - Measures of centrality of extrinsic motivational factors (average)

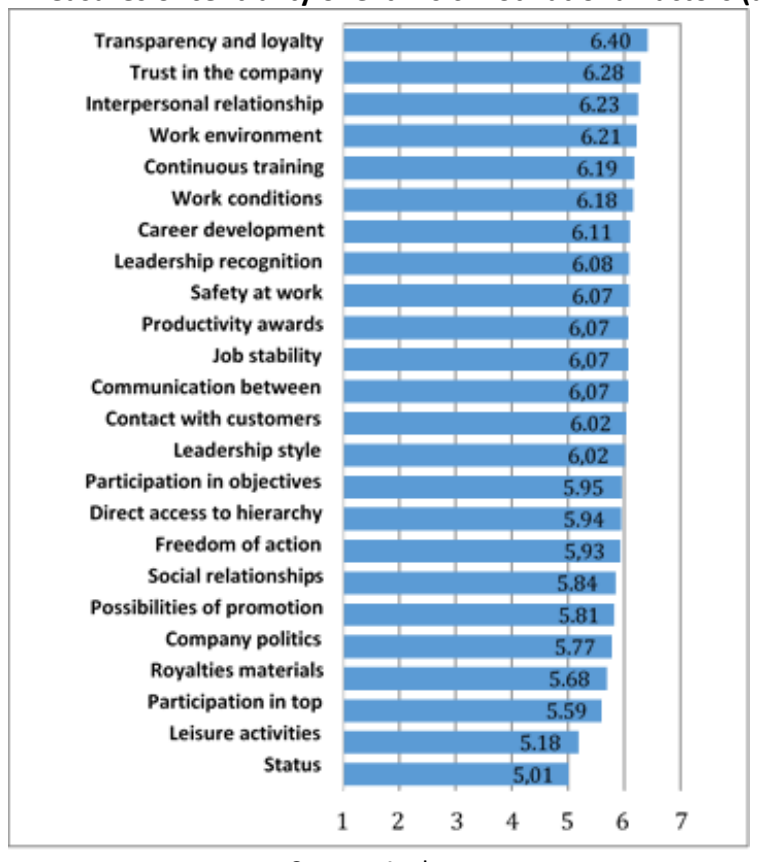

Source: Author.

Regarding performance, the variables 'attitude' and 'commitment' have the highest averages, as shown in Figure 4. The variables 'customer satisfaction' and 'achievement of goals and objectives' were given greater importance by the respondents.

Figure 4 - Measures of centrality of behavioural performance and performance results (average)

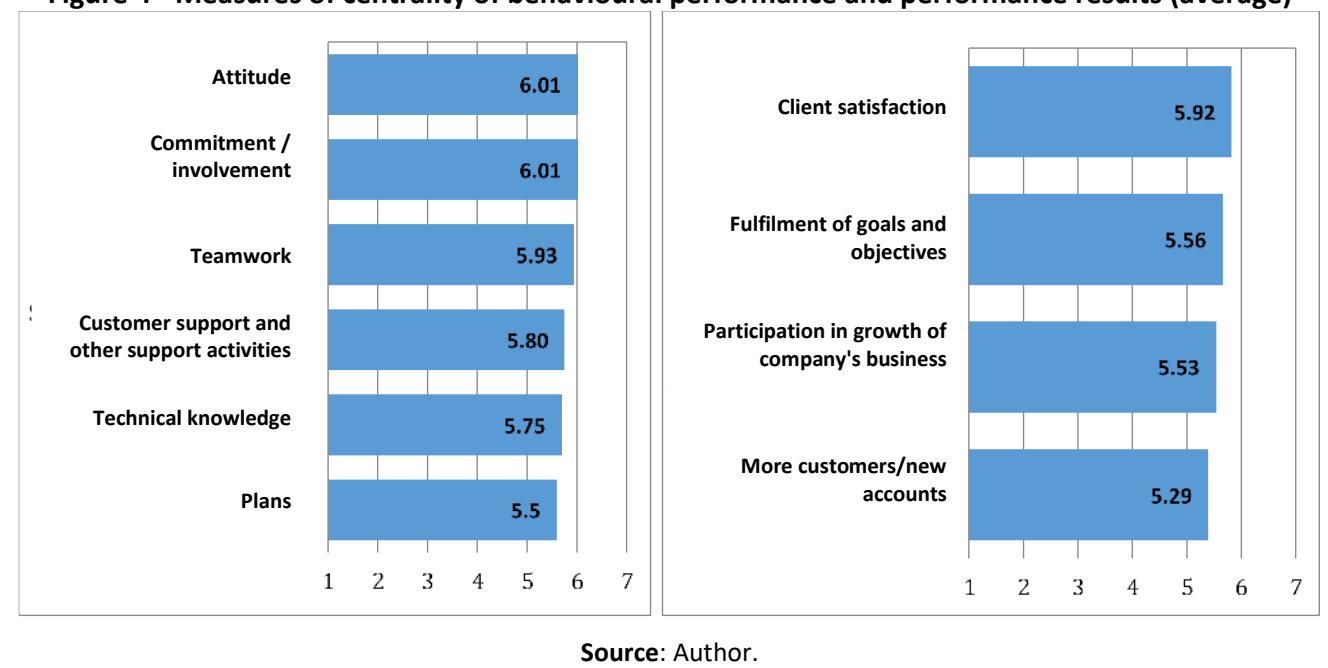

The proposed structural model suggests that intrinsic and extrinsic factors affect motivation. In order to measure the direct effect of motivation on behavioural and performance results, these constructs were analysed using regressions, followed by path analysis (Marôco, 2010).
As shown in Figure 5, the factorial weight of intrinsic factors in motivation is one, and the factorial weight of the extrinsic factors is 0.98 . All variables present positive factor weights reaching maximum values that confirm hypotheses $\mathrm{H} 1$ and $\mathrm{H} 2$. Motivation has a relatively strong and significant positive effect on performance results $(0.54)$ and a weaker impact on behavioural performance (0.41), confirming hypotheses $\mathrm{H} 3$ and $\mathrm{H} 4$.

Figure 5 - Confirmation of hypotheses

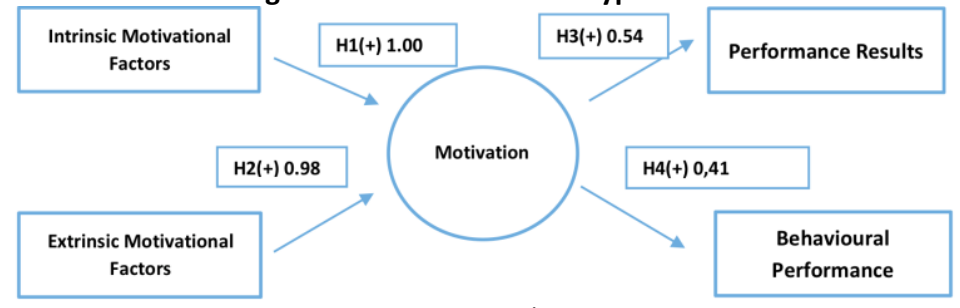

Source: Author. 


\section{Conclusions}

The conclusions we have drawn have implications primarily for managers of pharmaceutical sales teams, but we also believe that the results could be of interest to managers working in other sectors, given that maintaining teams motivated, satisfied and committed is a common management goal. This study showed that the theories of motivation reviewed complement each other and contribute to the design of a more comprehensive perspective on individuals' natural complexity in this area.

The results of the present research on intrinsic and extrinsic motivational factors indicate that the intrinsic variables that best explain motivation are 'personal goals' and 'skills acquired' The extrinsic variables that best explain motivation are 'transparency and loyalty in interactions with bosses' and 'trust in the company'. Motivation influences behavioural performance more than performance results. Individuals with a better attitude (i.e. a behavioural variable) who participate in their company's business growth (i.e. a results variable) are more motivated and achieve a higher level of performance.

The results also indicate that intrinsic factors such as 'autonomy' and 'responsibility' and extrinsic factors such as 'interpersonal relationships', 'work environment', 'working conditions' and 'participation in objectives' play a significant role in the sales teams' overall motivation. This study's findings confirm that managers need to pay attention to the most important factors influencing the motivation of their companies' sales force in order to optimise these factors.

This research's limitations include some restrictions to the generalisation of results due to the size and type of sample used. Future research could replicate this study in other sectors of activity.

Organisations need to change the way they view motivation, so the results of empirical research on this subject, such as those of the present study, need to be disseminated so that their benefits are clear. Managers can use these to optimise their organisational policies and strategies to enhance their employees' satisfaction, performance and sales earnings.

\section{References}

Alderfer, C.P. (1972). Existence, Relatedness, and Growth: Human Needs in Organizational Settings. New York: Free Press.

Almeida, M.C. (1996). Auditoria: Um Curso Moderno e Completo. 5a Ed. São Paulo: Atlas.

Anderson, E. \& Oliver, R.L. (1987). Perspectives on behavior-based versus outcome-based salesforce control systems, Journal of Marketing, 51(4), 76-88.

Babakus, E., David, W.C, Mark, J. \& William, C. M. (1996). Examining the Role of Organizational Variables in The Salesperson Job Satisfaction Model. Journal of Personal Selling \& Sales Management, 16(3), 33-46.

Behrman, D.N. \& Perreault, W.D. Jr. (1982). Measuring the Performance of Industrial Salespersons. Journal of Business Research, 10, 355-369.

Chiavenato, I. (1999). Gestão de Pessoas - O novo papel dos recursos humanos nas organizações. Rio de Janeiro: Campus.

Churchill, G.A, Ford, N.M., Walker, O.C., Johnston, M.W. \& Tanner, J.F. (2000). Sales Force Management: Planning, Implementation and Control. $6^{\text {th }}$ Ed. Auckland: Irwin/MacGraw-Hill International Edition.

Churchill, G.A., Ford, N.M., Hartley, S.W. \& Walker, C.O. (1985). The Determinants of salesperson performance. A meta-analysis. Journal of Marketing Research, 22, 103-118.
Cravens, D.W., Ingram, T.N., LaForge, R.W. \& Young, C.E. (1993). Behaviorbased and outcome based salesforce control systems. In J.P. Jaramillo \& G.W. Marshall (2005). A MetaAnalysis of the Relationship Between Organizational Commitment and Salesperson Job Performance: 25 Years of Research. Journal of Business Research, 58, 705-714;

Cunha, M.P, Rego. A., Cunha, R.C. \& Cardoso-Cabral, C. (2007). Manual de Comportamento Organizacional e Gestão. 6a Ed. Lisboa: Editora RH.

Deci, E.L. \& Ryan R.M. (1985). Intrinsic Motivations and self-determination in human behavior. New York: Plenum.

Hackman, J.R. \& Oldham, G.R. (1976). Motivation through the design of work: Test of a theory. Organizational Behavior and Human Performance, 16(2), 250-279.

Herzberg, F. (1968). One more time: How do you motivate employees? Harvard Business Review, 40(1), 53-62.

Küster, I. \& Canales, P. (2008). Some determinants of salesforce effectiveness. Team Performance Management, 14(7/8), 296-326.

Locke, E.A. \& Latham, G.P. (1984). Goal setting: A motivational technique that works. Englewood Cliffs N.J: Prentice- Hall.

Marôco, J. (2010). Análise de Equações Estruturais: Fundamentos Teóricos, Software \& Aplicações. Pero Pinheiro: ReportNumber, Lda.

Maslow, A.H. (1954). Motivation and personality. New York: Harper and Row.

McClelland, D.C. (1961). The Achieving Society. University of Illinois at Urbana-Champaign's Academy for Entrepreneurial Leadership Historical Research Reference in Entrepreneurship.

McGregor, D. (1960). The Human Side of Enterprise. New York: McGrawHill.

Oldham, G.R. \& Hackman, J.R. (2010). Not what it was and not what it will be: The future of job design research. Journal of Organizational Behavior, 31(2-3), 463-479.

Piercy, N.F., Cravens, D.W., Lane, N. \& Vorhies, D. (2006). Driving organizational citizenship behaviors and salesperson in-role behaviour performance: The role of management control and perceived organizational support. Journal of the Academy of Marketing Science, 34(2), 244-262.

Rodrigues, J.V., Guerra P.B. \& Câmara P.B. (1997). Humanator. Lisboa: Publicações D. Quixote.

Rosa, L. (1994). Cultura empresarial: Motivação e Liderança. Lisboa: Editorial Presença.

Shapiro, B.P. (1988). The High Impact Salesforce - The Investment You Can't Afford Not to Make. Boston: Harvard Business School.

Spiro, R.L., Rich, G.A. \& Stanton, W.J. (2009). Gestão da Força de Vendas. New York: Editora McGraw-Hill.

Stanton, W.J. \& Spiro, R. (2000). Administração de Vendas. Tradução Dalton Conde de Alencar. 10a Ed. Rio de Janeiro: LTC - Livros Técnicos e Científicos Editora S.A.

Taylor, F.W. (1911). The Principles of Scientific Management. Harper \& Row.

Vroom, V.H. (1964). Work and motivation. San Francisco, CA: Jossey-Bass. Walker, O.C., Jr., Churchill, G.A.Jr. \& Ford, N.M.F. (1977). Motivation and Performance in Industrial Selling: Present Knowledge and Needed Research. Journal of Marketing Research, 14(2), 156-68.

Received: 25 June 2015

Revisions required: 13 May 2016

Accepted: 10 November 2016 